\title{
Customer Satisfaction towards Online Car Insurance at South Tamilnadu a Special Reference with Madurai and Sivaganga District
}

\author{
K.Chandrasekar, Karthick R
}

\begin{abstract}
This paper aims to find customer satisfaction towards online car insurance at south Tamilnadu, especially Madurai and Sivaganga district. According to the various literature reviews, the researcher has found the factors of the study such as trust, service-quality and risk. All the three factors have different variables. In the study used in primary data through questionnaire method, 115 sample size have been collected for analysis of research study. The results evince a strong correlation between trust and service-quality, and positive correlation between trust and risk. All the three factors are considered as a strong impact of online customer satisfaction.

Keywords: Online Customer Satisfaction, Car Insurance Satisfaction, Online Insurance Satisfaction.
\end{abstract}

\section{INTRODUCTION}

"A customer is the most important visitor on our premises. $\mathrm{He}$ is not dependent on us. We are dependent on him. He is not an interruption of our work. He is the purpose of it. He is not an outsider of our business. He is part of it. We are not doing him a favour by serving him. He is doing us a favour by giving us the opportunity to do so."

- Mahatma Gandhi

Every business and organizations depends their customers. Customer is seen as a king of our business premises. Without customer we cannot do our business. So, all the organization tries to retain their customers. If they want to retain the customers, the business organization should provide more offers, scheme and benefit to their customers. By giving these benefits, they attract the same customers to retain the same company or else they switch over to other company. Especially in the insurance industry, it's very difficult to retain their policy holders.

Revised Manuscript Received on July 22, 2019.

Dr.K.Chandrasekar, Assistant Professor-cum-Placement officer, Alagappa Institute of Management, Alagappa University, Karaikudi, Email: chandrasekar77@gmail.com

Dr.Karthick R., Assistant Professor St. Joseph's College of Engineering, Chennai, Email: Karthick0528@gmail.com

The insurance industry is the very oldest industry in the world. Marine insurance is the oldest form of insurance followed by life insurance and fire insurance. The history of insurance can be traced back to early civilization. Last few years every business organizations have been encouraging the online business model. The insurance industry also booming industry as well as encourage online business practices. Some of the car insurance holders buy car insurance only through the direction of the government. Some of the insured not aware of insurance benefits and schemes so they are all not willing to buy insurance.

According to Peter Maas (2008), customers think about insurance differently and want to be treated in different ways. Insurers have been trying to cope with this diversity by using specific marketing campaigns to target select customer segments, based mainly on socio-economic parameters like age or income. Ernst \& Young Global insurance survey (2012) argue that some customers need the cheapest offer, or looks for convenience and service, or is open to usage-based insurance.

The customer or insurance holder or insured directly buy an insurance product or policy. It means people are buying an insurance policy or products without seller's interaction. They are buying a policy with the help of their own knowledge and previous experience through the online dealings. In fact, people will determine the suitable policy; insured's declared value, claim process and procedure, insurer previous relationship, risk level and finally selection of the insurer. Therefore, this study aims to identify customer satisfaction on online car insurance in south Tamilnadu especially Madurai and sivaganga district.

\section{LITERATURE REVIEWS}

Shuchi Singhal and Shashi Shekhawat (2014) the researcher focused on customer satisfaction in online shopping. The result established two kinds of factors like factors resisting online shopping - complexity, Security, Lack of human contact, Technology failure, Fake portals, End products vary than original and another one depends customer satisfaction parameters -Purchase experience, Service Quality, Query Resolving process, Overall purchase experience after online

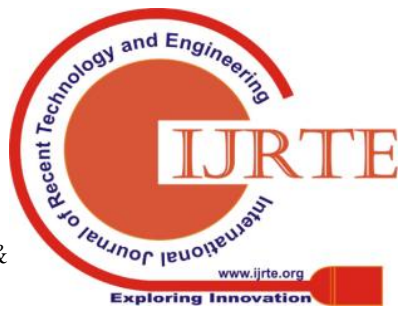


shopping and Repeat purchase experience. The highlights of the study result is the factor which is showing highest correlation is complexity in online shopping with service quality, repeat purchase experience and query resolving process because more complexity means more features and facilities are there in web purchasing. Among them price, speed and accuracy of information, customized products availability, ease of accessing websites, loyalty for online portals- the ease of website assessing is the parameter of online customers which affects mostly the customer satisfaction as per 26 per cent of 76 people.

Dost (2015), product or services brought by the customer should satisfy the customers and an important thing in the business. The quality is the important character of the product and services. The customer brought some product or online services online if the retailer also sells the same product, the customers buy a product or services through online and they anticipate some advantage of the purchase process. In his observation, the security and privacy are important elements of the online purchase by transaction. Here, the risk like product risk and monetary risk are more highlighted.

Lakshmi (2016) the author mentioned the fact about online purchases when customers are purchasing through online they cannot touch or feel the product. They read the given information of product provided by the online seller. It influences the buyer's decision to buy a particular online product. Product information may satisfy customer demands and comparison with customer of other online competitor. The online retailer provided some needed information which will be created as trust among the online buyer. This is because the seller has succeeded in fulfilling all consumer needs and wants. Trust appears to be an important factor in the buyer's online shopping decisions.

Sevim (2014) argued that risk and the doubtful situation in online shopping which will created as psychological impact for the customer satisfaction through previous experiences, beliefs and feelings. It certainly influences the decision on the online purchase. Technology is a tool to disseminate the product details to attract customers by using the website design, product information, online transaction, search engine, sitemaps and search results pages which make the purchase easier. It helps customer and sellers to communicate easily.

Rajeswari $M$ (2015) in her study, she investigates the customer satisfaction towards online shopping and finds the factors that influencing customer's online shopping decision and factors those affect customer satisfaction. The researcher uses variable advantages of online purchase like quality and availability of the product, mode and speed of delivery of the product, product price / offers provided for online shoppers, payment options available for the customers, shipping, returning and exchanging policies, and features of the shopping website(design, information provided, accessibility, and ease of use). The customer perceptions, preferences, factors influencing the satisfaction of the online buyer, decreasing customer's perceived risks, providing secure payment and ensuring speed and quality of delivery to increase customer make trust among the customers.
Paramita Saha and Yanni Zhao (2005) the researcher has chosen online services quality to increase customer satisfaction. Online services delivery system is one of the difficult processes to manage the quality of the service. Their study is an aim to get a better understanding of the service quality which affects customer satisfaction in the internet banking perspective. This study has been used nine services quality dimensions like efficiency, reliability, responsiveness, fulfilment, privacy, communication, personalization, technology update, and logistic/technical support. All the dimensions are having a strong impact on customer satisfaction. Finally, the researcher found two new dimensions namely technology update and logistical or technical support.

Yue-Yang Chen, et al., (2011), in their study, they investigate the quality of customer's e-satisfaction and e-loyalty in online shopping. Consumers may buy directly from the online market which is easy and flexibility with price and convenience. The aim of this research is to inspect the relationships among "product quality", "information quality", "system quality", "e-Service quality", "e-Satisfaction", and "e-Loyalty". The four antecedents had significant positive correlated on online customer's e-Satisfaction that turned into customer's e-Satisfaction which also have a positive impact on customer's e-Loyalty.

Rashed Al Karim(2013) In his paper, he analysed that Customer Satisfaction in Online Shopping is a reason for motivations and inhibitions for customer attraction. It is discovered the respondents to use internet for purchasing products through online. Because they believe in convenience of customers and the term convenient includes elements such as time-saving, information availability, opening time, ease of use, websites navigation, less shopping stress, less expensive and shopping fun. In contrast, along with respondents' mind-sets, online payment security, personal privacy and trust, unclear warranties and returns policies and lack of personal customer service are the foremost barriers of online shopping. Online payment system and privacy or security anxieties have a significant impact on online shopping. Finally, online retailers to take initiatives for making online shopping more admired and trustworthy.

Zainal N.A.A and Bahrom N.A.M (2018 in his study, he aims to identify the factors that influence customer satisfaction online shopping. Trust and service quality are leading customers' satisfaction towards online shopping behaviour. The result reveals that trust and service quality is to act a medium of customer satisfaction. Product or service brought online transaction, risky and doubtful situation, web design those variables are lead trust and reliability, assurance, responsiveness. Quality of web design and quality of product or service information are lead to e-service quality. Both trust and e-service quality is lead to customer satisfaction toward online shopping.

\section{IDENTIFICATION OF THE PROBLEM}

The insurance industry is one of the oldest industries in the world. First insurance company stared at the 14th century; the insurance industry is the only industry still doing

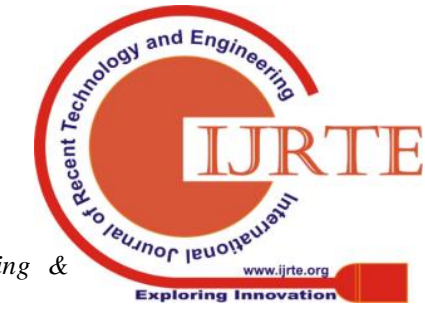


successfully business and compare with other industry. First, they are dealing with marine insurance only in the evaluation of the world, the insurance industry also evaluated simultaneously.

The insurance industry is one and only industry safeguard to the insured life as well as properties, nowadays every industry encourage and adopt the online mode for the customer convinces. So the insurance industry also has adopted online services mode of past few years.

In this study, the researcher identify the online car insured satisfaction level in south Tamilnadu especially Madurai and sivaganga. The researcher used Trust, services quality and risk as research parameters to evaluate the customer satisfaction level in online car insurance.

\section{A. Objectives of the Study}

- To identify the customer satisfaction of online car insurance.

- To evaluate customer satisfaction through trust services quality and risk of the online car insurance.

- To identify and reveals the relationship between the factors.

\section{B.Hypothesis of the Study}

- The Services quality and the risk do not have an influence on Trust.

- There are no correlations among the variables of customer satisfaction in online car insurance.

\section{RESEARCH METHODOLOGY OF THE STUDY}

In this study, the researcher is dealing with customer satisfaction of online car insurance. The research area of the study is south Tamilnadu especially Madurai and Sivaganga district. The population of the study is based on those who have own car as well as proper renewal of car insurance through online mode. The people who have own car, has been taken to research study on customers satisfaction of online car insurance.

\section{A.Sample size}

The research population is too large. According to Raosoft online sample calculator, research has a population size is more than 20,000 . Thus, the research population is considered as an infinite. So, the study also consider as an infinite population due to its sample size.

\section{A.Sampling method}

Collecting samples from respondents is to give equal representation to both districts. In this study, the researcher has used snowball sampling method for sampling techniques. The researcher finds the first respondent who comes under the criteria of research study and gets filled questionnaire from him. The first respondent suggests his known people, who has own car is taken to further research study. Recommendations from the respondents are taken to choose other respondents who also meet the criteria. In this research, snowball sampling helped in identifying more respondents who contributed many valuable insights into the study.

In this study mainly focused on the customer satisfaction level of online car insurance, so it was used primary data as well as secondary data. The primary data collected through the questionnaire method.

\section{V.RESULTS}

\section{A.Multiple Regression: \\ Multiple Regression to find the impact of Trust through Service Quality and Risk.}

Hypothesis: services quality and risk do not have an influence on Trust.

Table - 1 (A) Model summary

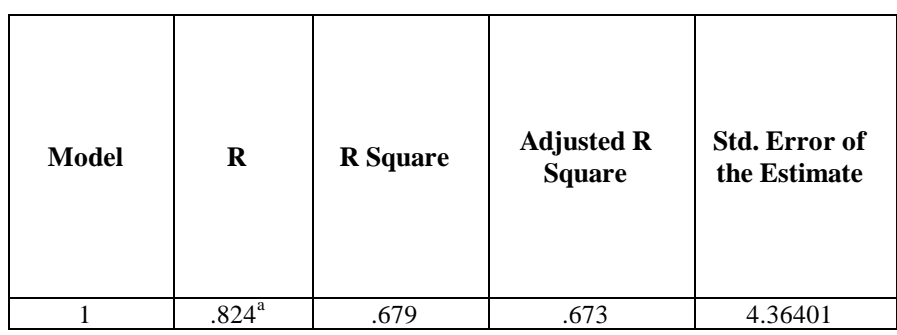

a.Predictors: (Constant), Risk, Services Quality

Table - 1 (B) ANOVA

\begin{tabular}{|c|c|c|c|c|c|}
\hline Model & Sum of Squares & df & $\begin{array}{c}\text { Mean } \\
\text { Square }\end{array}$ & F & Sig. \\
\cline { 1 - 4 } Regression & 4503.498 & 2 & $\begin{array}{c}2251.74 \\
9\end{array}$ & \multirow{2}{*}{$\begin{array}{c}118.23 \\
6\end{array}$} & $\begin{array}{c}.000 \\
\mathrm{~b}\end{array}$ \\
\cline { 1 - 4 } Residual & 2132.989 & $\begin{array}{c}11 \\
2\end{array}$ & 19.045 & \\
\cline { 1 - 4 } Total & 6636.487 & $\begin{array}{c}11 \\
4\end{array}$ & & \\
\hline
\end{tabular}

a. Dependent Variable: Trust

a.Predictors: (Constant), Risk, Services Quality

Table - $1\left(\right.$ C) Coefficients ${ }^{a}$

\begin{tabular}{|c|c|c|c|c|c|}
\hline \multirow{2}{*}{ Model } & \multicolumn{2}{|c|}{$\begin{array}{c}\text { Unstandardized } \\
\text { Coefficients }\end{array}$} & $\begin{array}{c}\text { Standardized } \\
\text { Coefficients }\end{array}$ & \multirow{2}{*}{$\mathbf{t}$} & \multirow{2}{*}{ Sig. } \\
\cline { 2 - 6 } & $\mathbf{B}$ & $\begin{array}{c}\text { Std. } \\
\text { Error }\end{array}$ & Beta & & \\
\hline (Constant) & 5.677 & 2.638 & & 2.152 & .034 \\
\hline $\begin{array}{c}\text { Services } \\
\text { Quality }\end{array}$ & .452 & .073 & .572 & 6.230 & .000 \\
\hline Risk & .391 & .124 & .288 & 3.138 & .002 \\
\hline
\end{tabular}

a. Dependent Variable: Trust

Table 1 (c) shows that, the analysis of multiple regressions. It was carried out based on the enter method, this analysis to find out is there any significant impact among trust with service quality and risk. Services quality had a strong impact with a trust, the standardized beta is 0.572 . Risk had a positive impact on trust; the standardized beta value is 0.288 .

The overall model was described by 82 per cent of the variance in R-value, which is statistically significant, F (2, $112)=118.236, p<0.05$ to predict the Trust. The results of the regression analysis point out adjusted $R$ square of 0.673 and the F value 118.236 ( $\mathrm{p}<0.001$ ) on Trust. That is Trust among customer satisfaction level contribute for 67.3 per cent of the total variance in Services Quality and Risk. 
The $\mathrm{R}$ square and the adjusted $\mathrm{R}$ square indicate the model to fit at 67 per cent respectively.

\section{B. Multiple Correlation:}

Correlation among the variable of customer satisfaction

Hypothesis: There is no correlation between the variables of customer satisfaction.

Table - 2 Correlation among the variable of customer satisfaction

\begin{tabular}{|c|c|c|c|}
\hline $\begin{array}{c}\text { Components of Customer } \\
\text { Satisfaction }\end{array}$ & Trust & $\begin{array}{c}\text { Services } \\
\text { Quality }\end{array}$ & Risk \\
\hline Trust & $\begin{array}{c}\mathbf{1 . 0 0 0}^{*} \\
*\end{array}$ & - & - \\
\hline Services Quality & $0.806^{* *}$ & $\mathbf{1 . 0 0 0}^{*}$ & - \\
\hline Risk & $0.753^{* *}$ & $0.812^{* *}$ & $\begin{array}{c}\mathbf{1 . 0 0 0} \\
*\end{array}$ \\
\hline
\end{tabular}

**. Correlation is significant at the 0.01 level (2-tailed) (P value is $<0.01)$.

The above table explicates of the correlation among the factors of customer satisfaction. It is to be positively significant among the entire three variables. The highest simultaneous variables are services quality and $\operatorname{risk}(\mathrm{r}=$ 0.812 ) followed by next highest correlated variable is Trust and Services Quality $(r=0.806)$ and finally least correlated variable is trust and risk $(r=0.753)$.

Hence, the p-value is less than 0.05 and the alternative hypothesis is accepted. In other words, the correlations are positively significant among all the variables of customer satisfaction.

\section{VI.FRAME WORK AND DISCUSSION OF THE STUDY}

In the prior studies, research show the factors influencing customer satisfaction towards online shopping such as trust, service quality and risk. As per the review of the literature, trust, service quality and risk are independent variables while influencing the customer satisfaction towards online shopping. Technology, product or services and risky situation are the main variables for the trust. Assurance, assistance, reliability and services information quality are the influencing variables for the service quality in online shopping. Finally, monetary risks as well as services risk are the variables to create as a risk factor.

These factors are determining customer satisfaction while buying online product or services. In this study, researcher focuses on customer satisfaction towards online car insurance.
A.
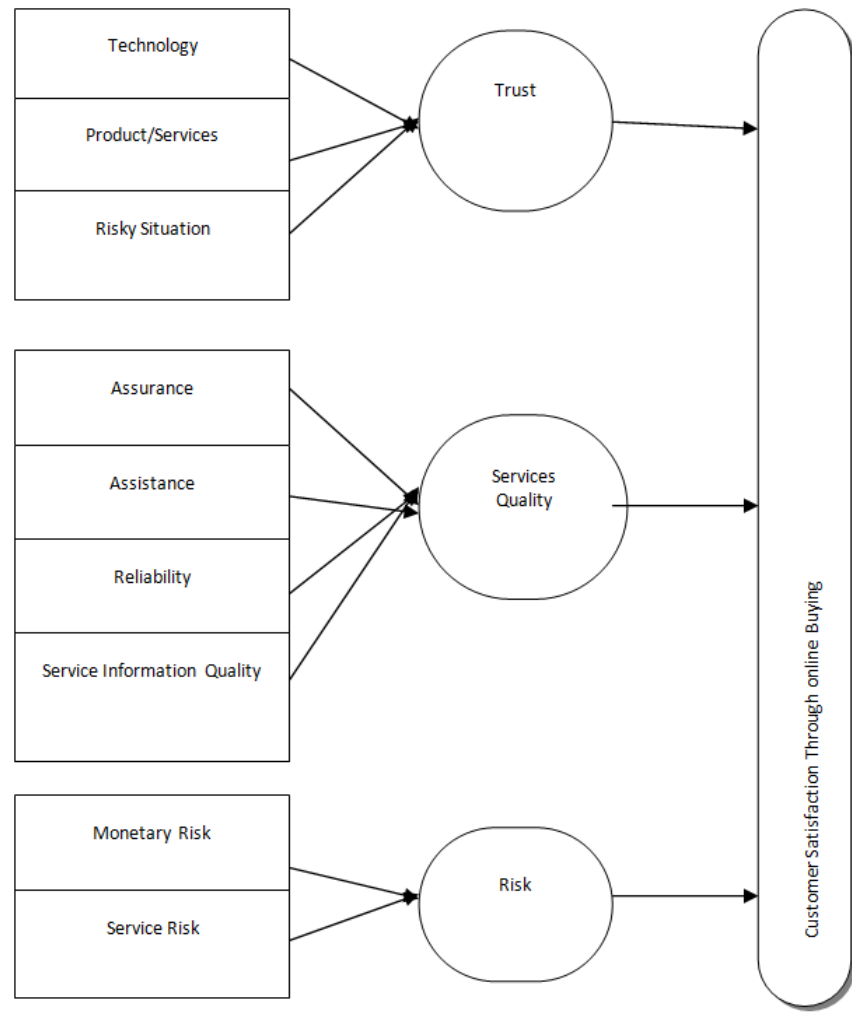

\section{B.Discussion}

This study is found out the significant impact among trust with service quality and risk. Services quality had a strong impact on trust and Risk had a positive impact on trust. The trust is a dependent variable. Similarly, trust will be changed on the basis of Services Quality as well as Risk. The correlation has been applied between the factors of online car insurance holders and customer satisfaction. It gives positive significance among the three variables. The highest simultaneous variables are services quality and risk followed by the next highest correlated variable is Trust and Services Quality and finally least correlated variable is trust and risk.

\section{ACKNOWLEDGEMENT}

We are grateful to acknowledge the sponsor from MHRD RUSA 2.0 scheme provided to Alagappa University, in successfully bringing out this research article.

\section{CONCLUSION}

The main objective of the research was to find out customer satisfaction towards online car insurance. In this study, researcher concluded that current online shopping authenticity and safety purchasing of products. But most of the people are not willing to buy

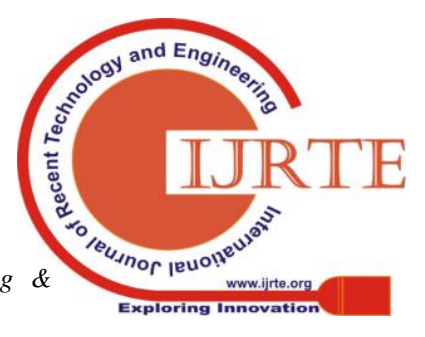


a service in online mode. This study shows the service also very trusty, less amount of risk and high quality of services for customers. Most of the car insurance holders thought showroom insurer is the first option because they take a less time to process a claim, but the online insurers also provide a quick claim procedure and effective communication before and after buying car insurance. They give effective add-on service proper renewal reminder and so on. Moreover trust, service quality and risk level is an influence in online customer satisfaction level vice versa.

\section{REFERENCES}

1. Al-Nasser, M. Et al. (2014). Relationship Amonrelationship among E-service Quality, Culture,, Attitude, Trust, Risk of Online Shopping. Journal of Social Sciences, 10(3), 123-142. Doi:doi:10.3844/jsssp.2014.123.142.

2. Carlson, Jamie \& O'Cass, Aron. (2011). Developing a framework for understanding e-service quality, its antecedents, consequences, and mediators. Managing Service Quality, 21(3), 264 - 286.

3. Chinomona, R.(2014). The Influence of E-Service Quality on Customer Perceived Value, Customer Satisfaction and Loyalty in South Africa . Mediterranean Journal of Social Sciences, 5(9), 331-341.

4. Dost, M. K. (2015). Online Shopping Trends and Its Effects on Consumer Buying Behaviour: A Case Study of Young Generation of Pakistan. NG-Journal of Social Development, VOL. 5, No. 1, October 2015 , $1-22$.

5. Shuchi Singhal, Shashi Shekhawat (2014), An Empirical Study of Customer Satisfaction in Online Shopping Experience of Tourism Products in India, International Journal of Scientific Engineering and Research (IJSER) www.ijser.in ISSN (Online): 2347-3878.

6. Liljander, Veronica \& van Riel, Allard \& Pura, Minna. (2002), Customer satisfaction with e-services: The case of an online recruitment portal. 10.1007/978-3-8349-4418-4_17.

7. Lucio Cappelli, Roberta Guglielmetti, Giovanni Mattia, Roberto Merli and Maria Francesca Renzi, (2011),"Testing a customer satisfaction model for online services", International Journal of Quality and Service Sciences, Vol. 3 Iss 1 pp. $69-92$.

8. M. Rajeswari (2015), A Study on the Customer Satisfaction towards Online Shopping in Chennai City, International Journal of Sales \& Marketing Management Research and Development (IJSMMRD), ISSN(P): 2249-6939; ISSN(E): 2249-8044, Vol. 5, Issue 1, Feb 2015, 1-10

9. Moshref Javadi, M. H., Dolatabadi, H. R., Nourbakhsh, M., Poursaeedi, A., \& Asadollahi, A.R. (2012). An Analysis of Factors Affecting on Online Shopping Behavior of Consumers. International Journal of Marketing Studies. Vol. 4(5), pp. 81-98.

10. parmita saha, yanni zhao (2005), relationship between online services quality and customer satisfation - a sstudy in internet banking, Lulea university of technology,2005:083 SHU - ISSN: 1404-5508 -ISRN: LTU - SHU-EX--05/083-SE

11. Rashed Al Karim(2013), Customer Satisfaction in Online Shopping: a study into the reasons for motivations and inhibitions, IOSR Journal of Business and Management (IOSR-JBM), e-ISSN: 2278-487X, p-ISSN: 2319-7668. Volume 11, Issue 6 (Jul. - Aug. 2013), PP 13-20

12. Sevim, N. (2014). Consumer Trust Impact on Online Shopping Intent. Journal of Internet Applications and Management, 19-28.

13. Taweerat Jiradilok, Settapong Malisuwan, Navneet Madan, and Jesada Sivaraks (2014), The Impact of Customer Satisfaction on Online Purchasing: A Case Study Analysis in Thailand, Journal of Economics, Business and Management, Vol. 2, No. 1, February 2014.

14. Yousif, A.S. H (2015). E-Service Quality: A Multi-Dimension Perspective. International Journal of Economicsm Commerce and Management, 3(11), 873-888.

15. Yue-Yang Chen, Hui-Ling Huang, Ying-Chen Chen (2011), A Quality-Centred View of Customer e-Satisfaction and e-Loyalty in Online Shopping, Advances in information Sciences and Service Sciences(AISS), Volume3, Number9, October 2011, doi : 10.4156/AISS.vol3.issue9.12

16. Zainal N.A.A and Bahrom N.A.M (2018), A Framework Based Customer Satisfaction Factors Towards Online Shopping, Research Hub Volume 4 Issue 3 (2018) Issn: 2180-0065 